\title{
Effect of Stirrups Orientation on Flexural Response of RC Deep Beams
}

\author{
Atteshamuddin S. Sayyad*, Subhash V. Patankar \\ Department of Civil Engineering, SRES’s college of Engineering, Kopargaon-423601, Maharashtra, India \\ *Corresponding author: attu_sayyad@yahoo.co.in
}

Received June 15, 2013; Revised July 16, 2013; Accepted July 18, 2013

\begin{abstract}
In this paper, the effect of stirup orientation on flexural response of reinforced concrete (RC) deep beams with two different shear-span-to-depth (a/d) ratios is presented. For RC beams with the same shear and flexural reinforcements, shear failure is most likely to occur in deep beams rather than in regular beams. Thus, solution for deep beams with shear deficiencies is of great importance. For that purpose a lateral, vertical and inclined stirrup design with two different ' $a$ /d' ratios is proposed. A series of tests were carried out in order to demonstrate the effect of proposed design. The test results of proposed lateral stirrup design indicated the increase of load carrying capacity. The present study shows that the ' $a / d$ ' ratio has more influence on the shear capacity, as ' $a / d$ ' ratio increases, the shear strength increases in case of short deep beam. The relative effectiveness of lateral (horizontal), vertical and inclined web reinforcement on the load capacity is mainly influenced by the 'a/d' ratio. The strength considered for investigation is flexural strength. Beam of size $700 \mathrm{~mm}$ X $150 \mathrm{~mm} \mathrm{X} 150 \mathrm{~mm}$ for flexure strength. The specimens were water cured for 28 days and tested with 2 point load subsequently.
\end{abstract}

Keywords: deep beam, orientation of stirrup, shear capacity, shear-spans-to-depth ratio, shear failure

Cite This Article: Sayyad, Atteshamuddin S., Subhash V. Patankar, "Effect of Stirrups Orientation on Flexural Response of RC Deep Beams.” American Journal of Civil Engineering and Architecture 1, no. 5 (2013): 107-111. doi: 10.12691/ajcea-1-5-4.

\section{Introduction}

Deep beam has always been a subject of interest in structural engineering practice. With the strong growth of construction work in many developing countries, deep beam design and its behaviour prediction is a subject of considerable relevance. A deep beam, generally speaking, is a beam having a depth comparable to the span length. A reinforced concrete member in which the total span or shear span is exceptionally s mall in relation to its depth is called a deep beam. Beams or components are considered deep when the shear-span-to-depth ratio ( $a / d$ ratio) is less than or equal to 2. Some researchers suggest that deep beam behaviour can exist to ' $a$ /d' ratio of 2.5 . Rein forced concrete deep beams have useful applications in tall buildings, offshore structures, and foundations. Mostly, deep beams occur as transfer a girder, which supports the load from one or more columns, transferring laterally to other columns. Deep beam action also occurs in some walls and pile caps.

A predominant failure mode of such members is shear failure and the shear action leads to compression in a diagonal direction and tension in a perpendicular thereto. The disturbance of internal stresses due to heavy concentrate loads causes deterioration in the load-carrying capacity of these members and fosters an abrupt shear failure as the overall depth of beam section increases. Thus, it is necessary to investigate the shear behaviour of deep beams according to various variables including section size. A relatively large number of studies have investigated the different main factors included in the problem: shear-span-to-depth ratio, cross sectional properties, amount, type and location of web reinforcement, concrete strength, size, shape and location of web opening.

Since the early 1900s, sectional truss models have made great contributions towards the shear design of shallow beams, but they are not suitable for deep beams due to them not satisfying the plane-section assumption. However, the strut-and-tie model (STM) has been widely adopted in the analysis and design of reinforced concrete deep beams for about twenty years, and recommended by numerous codes. It has also been used to analyse prestressed concrete deep beams by several researchers.

Gedik et al. [1] proposed a new stirrup design for short deep beams by considering three-dimensional effects such as lateral deformations and spalling of concrete. Stirrups are placed laterally in the shear span along the beam height in order to prevent lateral deformations by confinement effect. Mohammad et al. [2] studied the behaviour, design and analysis of high strength reinforced concrete (HSC) deep beams regarding the neutral axis variation and observed that, the strain distribution of deep beam is nonlinear before of tensile bars yielding state but it transforms to an almost linear state at ultimate condition due to horizontal steel bars behavior and crack progress. It was also evident that at the ultimate limit state, the stress distribution in compression area in the concrete is not parabolic as in the shallow beams. The intersection points 
of strain distribution decrease with the increase of the applied load. In other word the number of neutral axis depth will decreases after the yield point up to the ultimate load. Kim et al. [3] investigated structural behaviours of deep beams under combined axial and bending load. The deep beams are prepared to have different span-to-depth ratios from 0.5 to 1.5 and subjected to axial loads of $235 \mathrm{kN}$ and $470 \mathrm{kN}$. When the shear span-to-depth ratio decreases with increased axial load, the deep beam is failed due to concrete crushing before shear failure is occurred. These experimental results indicate that early failure of the beam is occurred due to concrete crushing when the deep beam is under axial load with relatively small shear span-to-depth ratio.

$\mathrm{Lu}$ et al. [4] proposed an analytical method for determining the shear strengths of steel reinforced concrete deep beams under the failure mode of concrete crushing originally based on the softened strut-and-tie model. The proposed method can accurately predict the shear strengths of SRC deep beams with vertical hoops or without vertical hoops. The major factors influencing the shear-carrying behavior of SRC deep beams have been found to be the ratio of the flange width to the gross width, shear-span-to-depth ratio, and the compressive strength of concrete. Yang et al. [5] interpreted the shear characteristics of high-strength concrete deep beams including size effects of beam section and evaluated the validity of the ACI code. Kotsovos et al. [6] have investigated the design of RC deep beams. Kong et al. [7] has given the formula for estimating the shear strength of reinforced concrete deep beams and for designing their web reinforcement and conclude that the ultimate shear strength of a deep beam is made up of 2 parts: the contribution of the concrete and that of the web reinforcement. Rajasekaran et al. [8] has developed theory to find compression depth as well as shear strength with or without web reinforcement. Kong et al. [9] studied the effect of inclined web reinforcement in RC deep beam Arabzadeh et al. [10] conducted an experimental and analytical investigation to study the behaviour of high strength RC deep beams and conclude that, the shear reinforcement are subjected to variable strains depends on their location in the span of the beams. The steel bars placed in central zone of shear span are subjected to higher strain than those placed near the support. Consequently it is probable that the shear reinforcement cannot attain their yielding force, it shall be considered in equilibrium conditions of strut-and-tie model.

\section{Test Program}

\subsection{Preliminary Test for Investigation}

Preliminary tests carried out on ingredients of concrete are as follows:

1). Cement- Concrete plus, which is specially formulated cement made by inter-grinding, higher strength ordinary Portland cement clinker with high quality processed fly ash. Since it utilizes a hazardous by-product of coal like fly ash, Concrete plus also helps in conserving the environment.

2). Aggregate: Locally available aggregates used are kept fairly uniform in size to minimize surface roughness and for a better aesthetic. The size of the aggregate used, can vary from $4.75 \mathrm{~mm}$ to $20 \mathrm{~mm}$.

a). Coarse aggregate (CA): Course aggregates of size $20 \mathrm{~mm}$ and $10 \mathrm{~mm}$ are used.

b). Fine aggregate (FA): Locally available river sand confirming to zone I is used as a fine aggregate.

The detail properties of CA and FA are given in Table 2.

Table 1. Preliminary tests data of cement

\begin{tabular}{|c|c|}
\hline Specific gravity & 3.15 \\
\hline Standard Consistency & 32.50 \\
\hline Fineness & $1.0 \%$ \\
\hline Initial setting time & $90 \mathrm{~min}$ \\
\hline Final setting time & $220 \mathrm{~min}$ \\
\hline Soundness & $3 \mathrm{~mm}$ \\
\hline \multirow{2}{*}{ Compressive strength } & 3 days $-19 \mathrm{MPa}$ \\
& 7 days $-28 \mathrm{MPa}$ \\
\hline
\end{tabular}

Table 2. Preliminary tests data of aggregates

\begin{tabular}{|c|c|c|}
\hline Test & CA & FA \\
\hline Specific gravity & 2.89 & 2.649 \\
\hline Water absorption test & $0.75 \%$ & $1.03 \%$ \\
\hline Bulk density(kg/L) & 2.79 & 2.33 \\
\hline Fineness modulus & 7.64 & 3.53 \\
\hline Aggregate Crushing value & $25.70 \%$ & - \\
\hline Aggregate impact value & $14.80 \%$ & - \\
\hline Elongation Index & 29.74 & - \\
\hline Flakiness Index & 31.12 & - \\
\hline
\end{tabular}

3). Steel: Tor steel of $10 \mathrm{~mm}$ diameter is used as main steel and of $6 \mathrm{~mm}$ diameter is used as shear reinforcement. Density of steel is $7850 \mathrm{~kg} / \mathrm{m} 3$ and yield strength of TOR steel and Mild steel is $500 \mathrm{Mpa}$ and $250 \mathrm{Mpa}$ respectively.

4). Water: Water that is potable is generally fine for use in the mix of $\mathrm{PH} 7.5$.

\subsection{Concrete Mix Design}

All test carried out on ingredient (Cement, coarse aggregate, fine aggregate and water) of concrete as per IS (Indian Standard) recommendation. Concrete mix design is done as per IS 10262-1982 for M20 grade of concrete. Following mix proportion is obtained after the concrete mix design.

\begin{tabular}{|c|c|c|c|}
\hline Water & Cement & Fine aggregate & Coarse aggregate \\
\hline 0.54 & 1.00 & 1.58 & 3.24 \\
\hline
\end{tabular}

Preliminary test on concrete with above mix proportion are carried out and following results are obtained.

\begin{tabular}{|c|c|}
\hline Workability & $100 \mathrm{~mm}$ \\
\hline Compressive Factor (for $100 \mathrm{~mm}$ slump) & 0.92 \\
\hline Compressive strength & $\begin{array}{l}7 \text { days }-16 \mathrm{Mpa} \\
28 \text { days }-28 \mathrm{Mpa}\end{array}$ \\
\hline Flexural strength & $3.90 \mathrm{Mpa}$ \\
\hline
\end{tabular}

\subsection{Testing of Specimens}

All beam specimens were of length $700 \mathrm{~mm}$ and crosssection $150 \mathrm{~mm}$ x $150 \mathrm{~mm}$. The prepared mix was poured into the steel mold as three layers of equal thickness compacted until the mix become homogenous. Beams were cured in the laboratory for a period of 28 days after casting in atmospheric temperature. Small reinforcement ratio of $1.4 \%$ was selected to minimize the effects of dowel action of reinforcement bars due to their layers and spacing. Eighteen specimens with the specification given 
in Table 1 were tested in order to investigate the effect of proposed positions of stirrup design for short deep beams. Details of specimens are given in Figure 1. The shearspan-to-depth ratio is 0.5 and 1.0. The yielding strength and elastic modulus of stirrup are $250 \mathrm{MPa}$ and $200 \mathrm{GPa}$ respectively. The thic kness of cover concrete was selected $25 \mathrm{~mm}$ to prevent a splitting failure of concrete. However the distance between two loading points for the specimen of was chosen according to ' $a / d$ ' ratio.

In the present study, the effect of stirrup orientation on flexural response of RC deep beam with two different shear-span-to-depth $(a / d)$ ratios. Lateral, vertical and inclined stirrups are provided. Beams with $a / d=0.5$ and 1 are considered for the detail experimental investigation.

$\mathrm{RC}$ beam with vertical stirrups in shear span is shown in Figure 1. RC beam with horizontal stirrups in shear span with vertical spacing $35 \mathrm{~mm}$ is shown in Figure 2. $\mathrm{RC}$ beam with inclined stirrups in shear span at an angle of $45^{\circ}$ is shown in Figure 3.

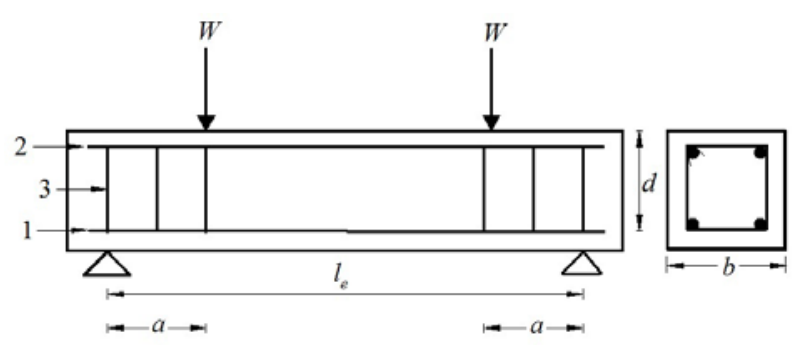

Figure 1. RC beam with veritcle stirrups

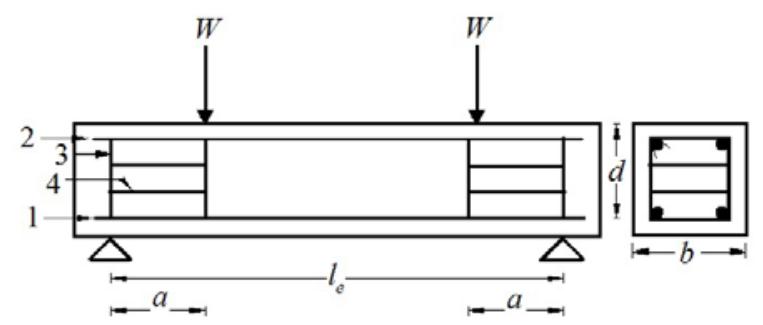

Figure 2. RC beam with lateral (Horizontal) stirrups

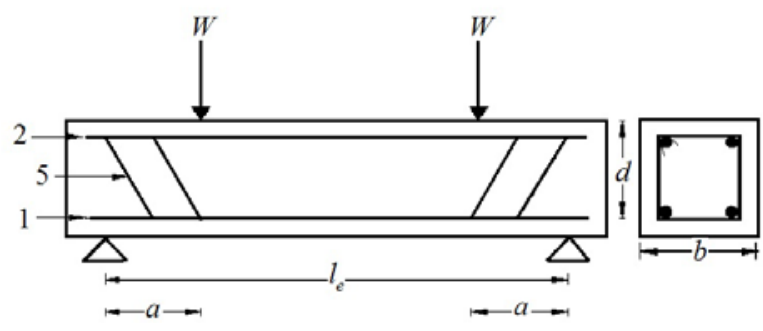

Figure 3. RC beam with inclined stirrups

Where,

1 = Longitudinal reinforcement (10 $\mathrm{mm}$ dia.)

2 = Anchor bar (10 $\mathrm{mm}$ dia.)

$3=$ Vertical shear re inforcement (6 $\mathrm{mm}$ dia.)

$4=$ Horizontal shear reinforcement ( $6 \mathrm{~mm}$ dia.$)$

5 = Inclined shear rein forcement ( $6 \mathrm{~mm}$ dia.)

$a=$ Shear span $(\mathrm{mm})$

$l_{\mathrm{e}}=$ Effective Span $(\mathrm{mm})$

$d=$ Effective depth $(\mathrm{mm})$

$b=$ Width of beam $(\mathrm{mm})$

The test specimen was mounted in loading frame of $1000 \mathrm{KN}$ capacity. The load was applied on two points according to shear span to depth ratio. The deflection was measured at mid span and different readings were recorded at increasing load. The failure mode of beam was also recorded. The test setup for the flexural test is shown in Figure 4.

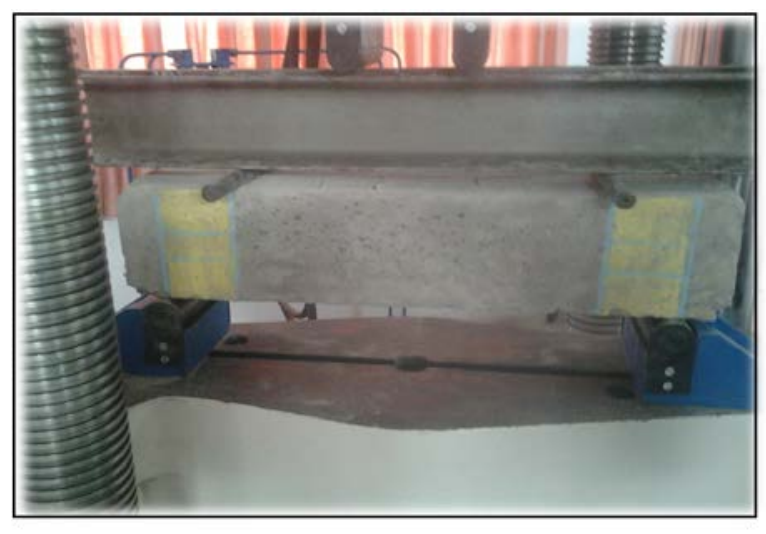

Figure 4. Flexural test setup of the RC beam

Table 4. Details of beam specimens

\begin{tabular}{|c|c|c|c|c|c|c|c|}
\hline $\mathrm{L}$ & $l_{e}$ & $D$ & $d$ & $b$ & $a$ & $a / d$ & $N$ \\
\hline 700 & 600 & 150 & 125 & 150 & 62.5 & 0.5 & 03 \\
\hline 700 & 600 & 150 & 125 & 150 & 125 & 1.0 & 03 \\
\hline 700 & 600 & 150 & 125 & 150 & 62.5 & 0.5 & 03 \\
\hline 700 & 600 & 150 & 125 & 150 & 125 & 1.0 & 03 \\
\hline 700 & 600 & 150 & 125 & 150 & 62.5 & 0.5 & 03 \\
\hline 700 & 600 & 150 & 125 & 150 & 125 & 1.0 & 03 \\
\hline
\end{tabular}

Where,

$L=$ Length of the beam $(\mathrm{mm})$

$l_{e}=$ Effective length of the beam $(\mathrm{mm})$

$\mathrm{D}=$ Overall depth of the beam $(\mathrm{mm})$

$\mathrm{d}=$ Effective depth of the beam $(\mathrm{mm})$

$\mathrm{b}=$ Width of the beam $(\mathrm{mm})$

$a=$ Shear span

$a / d=$ shear-span-to-depth ratio

$N=$ Number of specimens

\subsection{Test Results}

The results were tabulated in table no.1 and figures shows different crack pattern of the beam.

\begin{tabular}{|c|c|c|c|}
\multicolumn{5}{c}{ Table 5. Test results } \\
\hline $\begin{array}{c}\text { Orientation of } \\
\text { stirrups }\end{array}$ & $\begin{array}{c}a / d \\
\text { Ratio }\end{array}$ & $\begin{array}{c}\text { Average Flexural } \\
\text { Strengh (MPa) }\end{array}$ & $\begin{array}{c}\text { Increase in Flexural } \\
\text { Strengh (\%) }\end{array}$ \\
\hline Vertical & 0.5 & 38.47 & 0.00 \\
\hline Horizontal & 0.5 & 42.75 & 11.12 \\
\hline Inclined & 0.5 & 39.80 & 3.457 \\
\hline Vertical & 1.0 & 43.27 & 0.00 \\
\hline Horizontal & 1.0 & 48.81 & 12.80 \\
\hline Inclined & 1.0 & 43.76 & 1.132 \\
\hline
\end{tabular}

\section{Discussion}

The comparison of maximum flexural strength for vertical, lateral (horizontal) and inclined stirrups is shown in Table 5 . The examination of Table 5 reveals that shearspan-to-depth ratio has more influence on the shear capacity. The test result of proposed stirrups design indicates the increase in load carrying capacity of lateral stirrups compared to that of vertical and inclined stirrups. As a/d ratio increases, shear span also increases which contribute towards flexural capacity of beam. 
Figure 6 shows the failure of beam with vertical reinforcement specimen. As seen in the Figure 6, the compressive shear failure occurred leaded by diagonal shear crack with spalling of concrete. The failure of beam with lateral stirrups is shown in Figure 7. The lateral stirrups within the shear span were reduced the amount of spalling with confinement effect as seen. Moreover, the failure occurred with many shear cracks formed between stirrups rather than one main diagonal crack. Therefore, energy dissipation was increased and more ductile behavior occurred as well as the increase of load capacity. The failure of beam with inclined stirrups is shown in Figure 8. In this case, to resist or arrest diagonal shear crack the shear reinforcement is placed orthogonally to the shear crack. The cracks are propagated from point of loading towards side of shear span. Load deflection curves obtained during testing of beams on Universal Testing Machine (UTM) are shown in Figures 9 through 14.

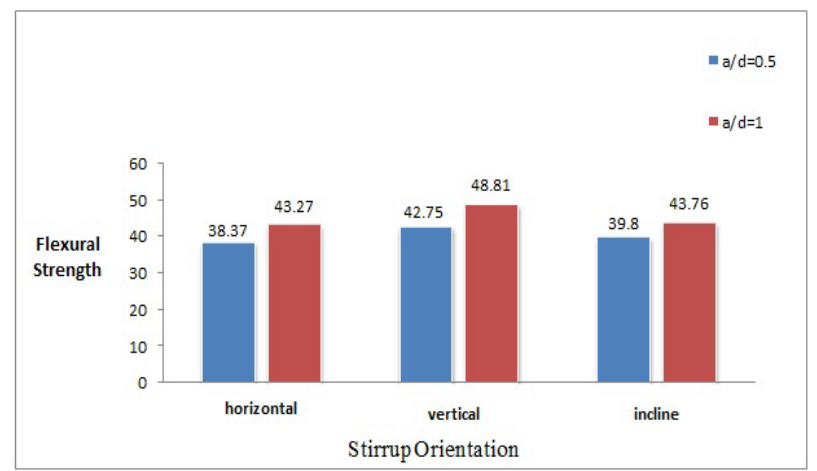

Figure 5. Maximum flexural strengh for the different stirrups orientation

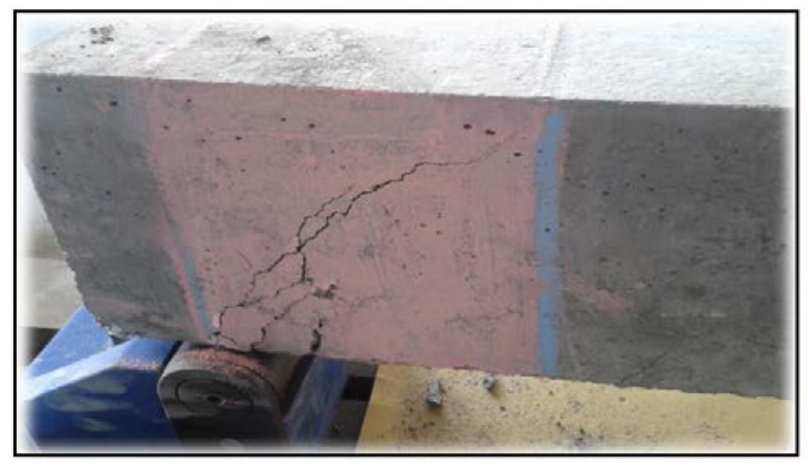

Figure 6. Grack pattern observed when vertical stirrups are provided in shear span

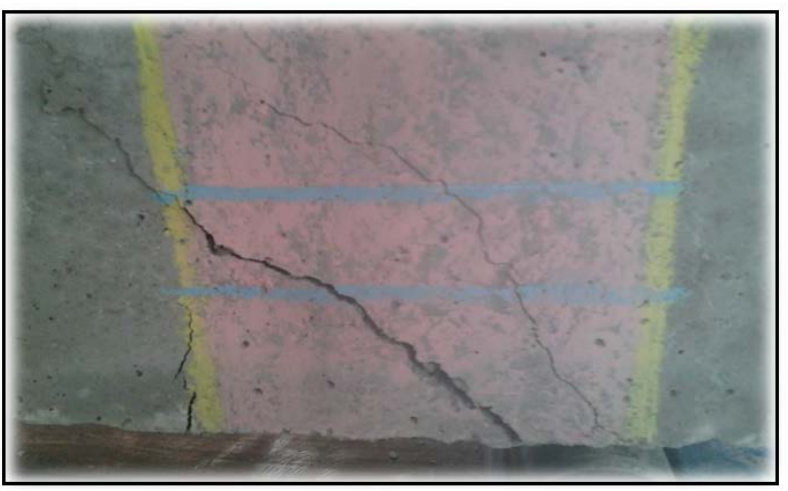

Figure 7. Grack pattem observed when lateral stirrups are provided in shear span

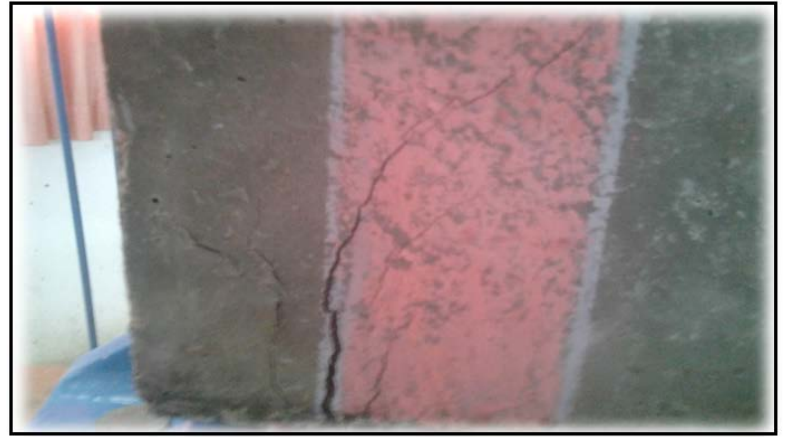

Figure 8. Crack pattern observed when inclined stirrups are provided in shear span

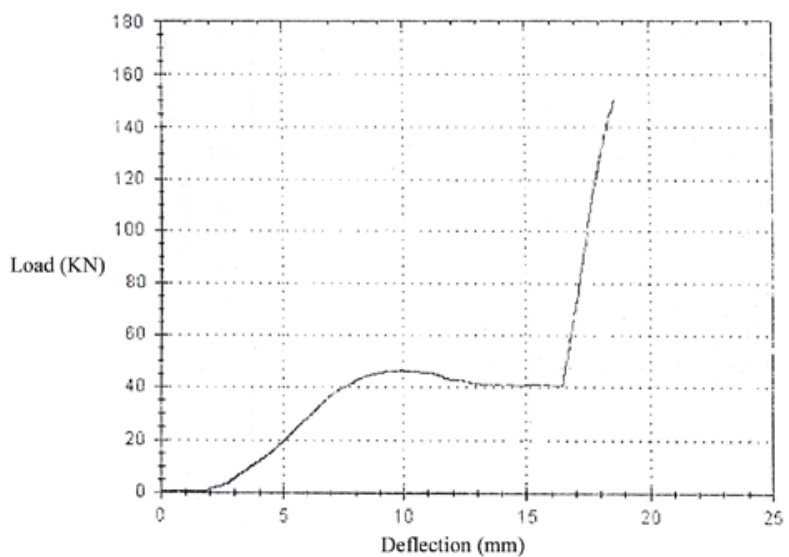

Figure 9. Load deflection curve for RC beam with vertical stirrups in shear span $(a / d=0.5)$

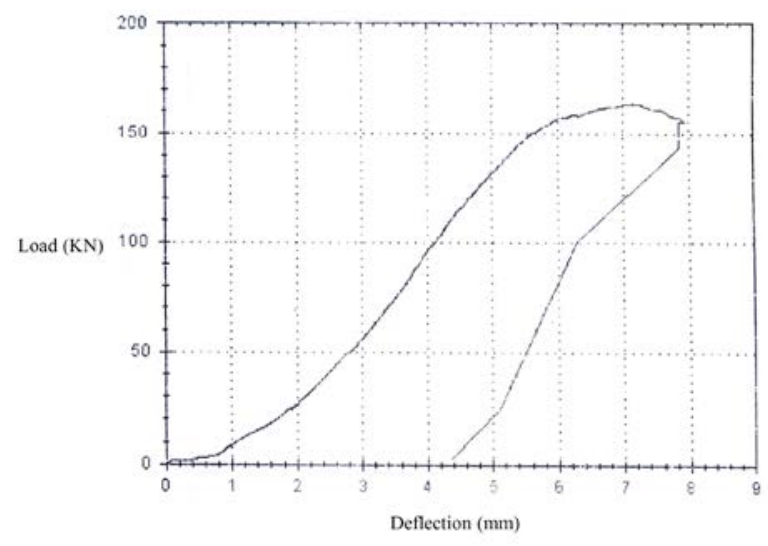

Figure 10. Load deflection curve for RC beam with vertical stirrups in shear span $(a / d=1.0)$

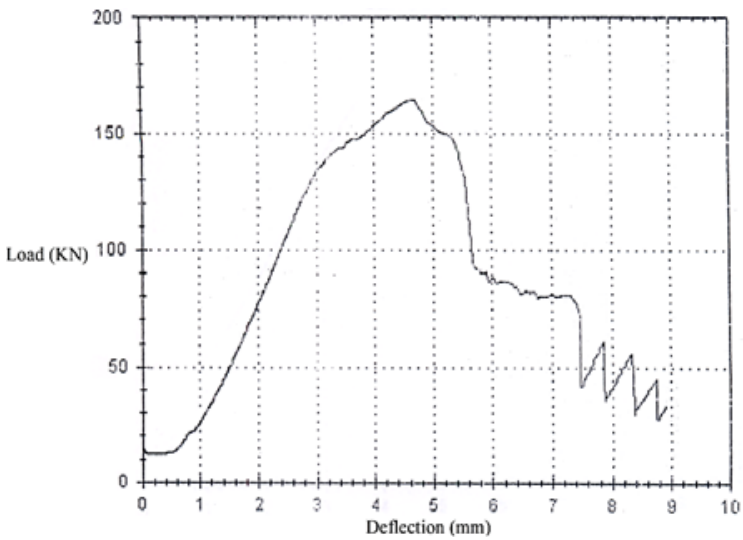

Figure 11. Load deflection curve for RC beam with lateral stirrups in shear span $(a / d=0.5)$ 


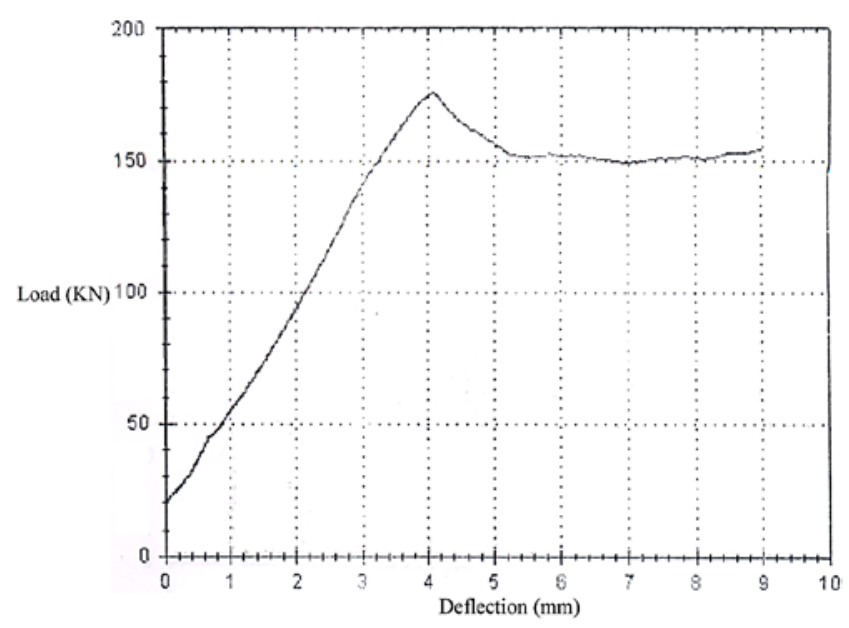

Figure 12. Load deflection curve for RC beam with lateral stirrups in shear span $(a / d=1.0)$

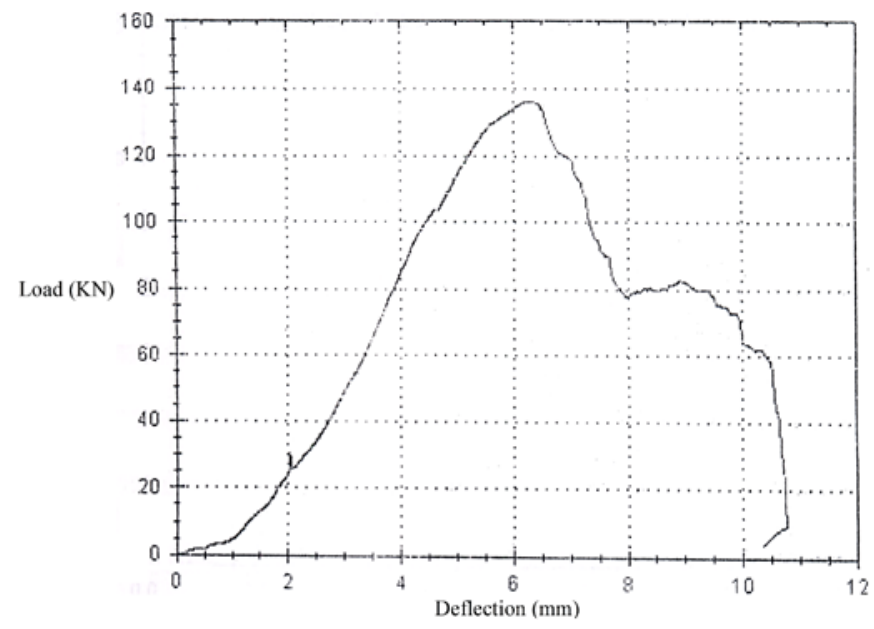

Figure 13. Load deflection curve for RC beam with Inclined stirrups in shear span $(a / d=0.5)$

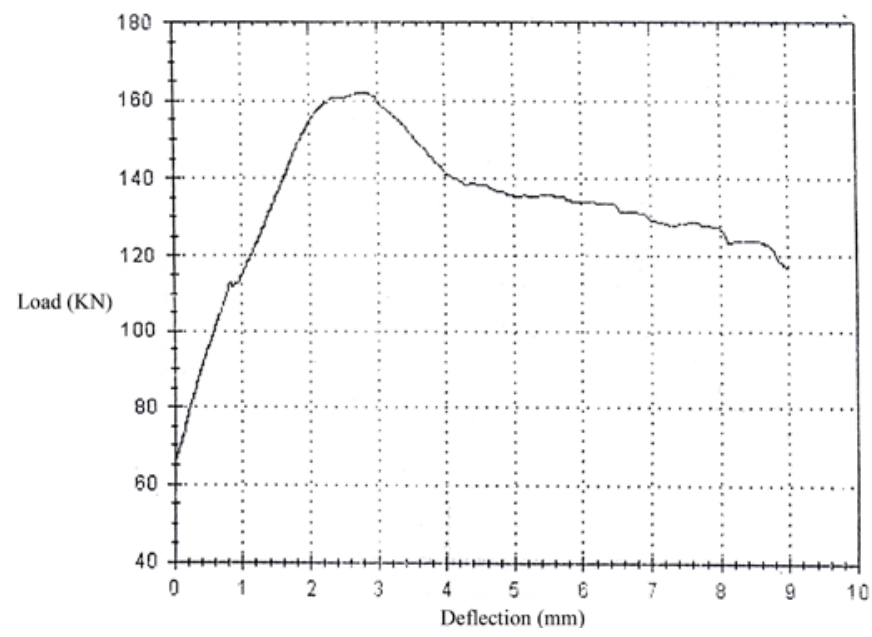

Figure 14. Load deflection curve for RC beam with Inclined stirrups in shear span $(a / d=1.0)$

\section{Conclusions}

From the experimental test results and discussion following conclusions are drawn.

1 In case of vertical stirrups with a/d ratio of 0.50 , shear cracks are arrested near neutral axis which shows ductile behaviour of beam. Whereas in case of horizontal and inclined stirrups orientation, flexural capacity increases but ductility reduces.

2 Lateral and inclined stirrups resist shear cracks more effectively than vertical stirrups.

3 Inclined stirrups prevent the diagonal cracks which are propagated from support towards load.

4 It is observed that in most of cases, initial cracks are developed on both support but final failure on one side only.

5 Cracks are slowly developed, which reflect the absence of thud/sudden failure.

\section{Acknowledgement}

This work is supported by graduate students, Amrutkar S.R., Kulkarni O.M., Deshmukh N.N., Kale S.U. and Kaushik A., Department of Civil Engineering, SRES's College of Engineering, Kopargaon-423601, Maharashtra, India.

\section{References}

[1] Gedik, Y.H., Nakamura, H., Ueda, N. and Kunieda, M. "A new stirrups design considering 3D effect in short deep beam," Procedia Engineering, 14. 2964 -2971. 2011.

[2] Mohammad, M., Jummat, M.B. and Chemrouk, M. “An experimental investigation of stress strain distribution in high strength concrete deep beam," Procedia Engineering, 14(2). 2141-2150. 2011

[3] Kim, H.S., Lee, M.S. and Shin, Y.S. "Structural behaviour of deep RC beam under combined axial and bending force," Procedia Engineering, 14. 2212-2218. 2011.

[4] Lu, W.Y. "Shear strength prediction for steel reinforced concrete deep beam," Journal of construction steel research, 62. 933-942. 2005.

[5] Yang, K.H., Chung, H.S., Lee, E.T. and Eun, H.C. "Shear characteristics of high strength concrete deep beam without shear reinforcements," Engineering Structures, 25. 1343-1352. 2003.

[6] Kotsovos, M.D. "Design of reinforced concrete deep beams," The Structural Engineer, 66(2). 28-32. 1988.

[7] Kong, F.K., Robins, P.T. and Sharp, G.R. "Shear analysis and design of reinforced concrete deep beams", The Structural Engineering, 50(10). 405-408. 1972.

[8] Rajasekaran, S. and Nalinaa, K. "Shear compression failure in reinforced concrete deep beam," Journal of Structural Engineering, 129(4). 544-553. 2003.

[9] Kong, F.K., Robins, P.J. Kirby, D.P. and David R. "Short deep beams with inclined web reinforcement” ACI Joumal, 69(16). 172-175. 1972.

[10] Arabzadeh, A., Aghayari, R. and Rahai, A.R. "Investigation of experimental and analytical shear strength of reinforced concrete deep beams," Intemational Journal of Civil Engineering, 9(3) 207-214. September.2011. 